\title{
石炭化学の最近の進歩 (そのI)
}

\author{
石炭の酸化亡酸化生成物の利用
}

\author{
平 尾一 郎*・藤本勉* \\ Recent Progress of Coal Chemistry. Part I. \\ Oxidation of Coal and Utilization of Oxidation Products.
}

Ichiro Hirao, Tutomu Fujimoto

\section{I. 緒言}

コークスおよび都市ガスを併産する石炭乾留工業が， ベンゾール，トルオール，キシロール，ナフタリン等, 化学工業原料の唯一の供給源として約 100 年にわたる長 、間，化学工業界に貢献してきたことは改めて申し上げ るまでもないことであり, 事実現在においても石炭化学 に負うところきわめて大なるものがある。ところが最近 の石油化学工業の発展に伴って石炭乾留工業によって得 られる有機化合物の一部，たとえばベンゾール，トルオ ールおよびキシロール等が石油化学工業によっても供給 されるようになった。

しかし一方，石炭について考察するとその主成分は石 油と同じく炭素であるが，石油が脂肪属炭化水素を主成 分とするのに対し, 石炭は分子量 2,000 以上の複合多環 式芳香族系炭化水素であるとはいえ，各種の炭素または 水素を含む化合物を合成する原料となることは石油と何 ら変りない。一方わが国の鉱産資源の生産額の $80 \%$ を 占めるものは実に石炭であって比較的に恵まれた資源で ある。したがって石炭の成分をなるべく完全にかつ有効 に利用するために石炭を化学原料として価值の高い化学 製品を製造又は合成する必要がある。従来の石炭乾留工 業によっても一応コークス, ガス, 粗軽油, コールター ル等が得られるが，石炭の 65〜70\% はコークスとなり， わずかに 5〜10\%しか得られないコールタールが石炭化 学工業の中心となっているにすぎない。さらにこれら粗 埾油およびュールタール中からは約 419 種にもおよぶ有 機化合物が確認発見されているが，工業的にはわずか 20 種足らずの成分が単離利用されているにすぎずコール

* 九州工籍大学工業化学科（北九州方戸畑区中原）
タールの主要分約 $80 \%$ はクレオソート油, ピッチなど の形で多数成分の混合体として利用されており, これら. の工業的分離, 利用は今後の研究にまつところ極めて大: なるものがある。したがってこれらとともに今後石炭の. 有効利用こそわれわれに課せられた大きな資務である。

このような情勢から石炭乾留, 完全ガス化, 直接水素. 添加, 溶剤抽出, 酸化など多くの領域にわたって新しい 石炭化学の研究開発が行なわれているが，これらの中， 特に興味哚く思われる石炭の酸化と生成物の利用, なら。 びに直接水素添加について最近の研究業續の進歩のあと. をひもといてみることにする。

\section{II. 石炭の酸化によるベンゼンカルボ ン酸類の製造}

石炭の低分子化の一つの手段として石炭の酸化, なら， びに石炭の化学的構造に関する研究が行なわれた。たと えば Bone $\mathrm{e}^{1)}$ らは石炭のアルカリ性過マンガン酸カリ酸. 化を行なって種々のベンゼンカルボン酸が生成すること を認め, 石炭の基本的構造はベンゼン核であることを明 らかにして石炭化学の基礎をつくった。最近では石炭よ り石炭の本質を有効に利用して化学原料を得る一つの方 法として石炭を酸化分解して工業的にベンゼンカルボン 酸類を得ようとする研究が行なわれている。

石炭を酸化分解してベンゼンカルボン酸類を工業的に 製造する方法としてはアルカリ水溶液中で酸素酸化を行 ならアルカリ酸化法と硝酸による硝酸酸化法が研究され

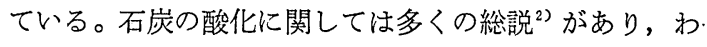
が国では樋口 ${ }^{3)}$, 安東 ${ }^{4)} ら の$ 総説がある。

1. 石炭のアルカリ酸素酸化 石炭をアルカリ水溶:

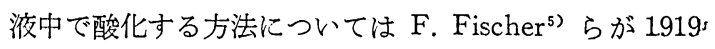


年にカツ炭を 炭酸ソーダ水溶液中で 反応温度 200 2 250 ${ }^{\circ} \mathrm{C}$, 圧力 $60 \mathrm{~atm}$ で空気酸化して, 水不溶酸 $4.5 \%$, 水 可溶酸 $43.1 \%$ を得, 水可溶酸中に酢酸, シュウ酸, お よび安息香酸, フタル酸などのベンゼンカルボン酸を確

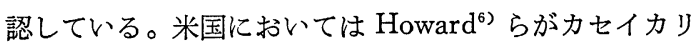
水溶液中で $250^{\circ} \mathrm{C}, 24 \mathrm{hr}$, 酸素圧 $9 \mathrm{~atm}$ で石炭を 酸素 酸化し芳香族酸を 38～39\% (炭素収支) の収率で得てい る。また彼ら ${ }^{7)}$ はカセイソーダ水溶液中でも石炭の酸化 を行なっている。フランスでは Germain ${ }^{8)}$ らが石炭を カセイソーダ水溶液中, 酸素圧 $85 \mathrm{~kg} / \mathrm{cm}^{2}$, 反态温度 $260^{\circ} \mathrm{C}$ で酸化を行ない，ベンゼンカルボン酸類の収率, 組成などについて検討している。わが国でも神谷9,10) ら が鹿町炭を用いてカセイソーダ, 炭酸ソーダなどのアル カリ水溶液中で石炭を酸素酸化し水可溶芳香族酸を約 $60 \%$ 得ている。ベンゼンカルボン酸は水可溶芳香族酸 中に約 $40 \%$ 含まれ, その成分について分離確認が行な われている。また芳香族カルボン酸類を酸化し, 石炭酸 化におけるベンゼンカルボン酸の生成機構について考察 されている11)。

i. 酸化生成物の収率とアリカリ 石炭をカセイアル カリ水溶液中で酸素酸化を行なう場合は反応によって生 成した有機酸を中和して安定化すると同時に, 多量に副 生する炭酸ガスを中和して反応を円滑に進めようとする もので, かなり多量のカセイアルカリの添加を必要とす る。したがってアルカリの種類, 添加量の反忘におよぼ す影響を検討することは重要である。

a. カセイソーダ Howard ${ }^{6)}$ らはカセイソーダを石 炭の約 7 倍量使用して，200 250 $\mathrm{C}$ で酸素酸化して詳 細に検討している。

カセイカリをカセイソーダにかえると反応速度が低下 することを認め, カセイソーダを用いたときの最適条件 を次のように示している ${ }^{12)}$ 。

石炭に対するカセイソーダの添加量 3 倍

反 応温度 $270^{\circ} \mathrm{C}$

反 応 洔間 $120 \mathrm{~min}$

酸素圧 $25 \mathrm{~kg} / \mathrm{cm}^{2}$

神谷 ${ }^{9}$ はカセイソーダの添加比 3〜3.5 (石炭に対する 重量比), 酸素初圧約 $40 \mathrm{~kg} / \mathrm{cm}^{2}$, 反応温度 $220 \sim 270^{\circ} \mathrm{C}$ でレキ青炭を酸化して, 未溶解炭, 水不溶酸, 水可溶芳 香族酸およびシュウ酸の収量の変化の様子を検討してい る (図 1，2参照)。その結果によると石炭の酸化の経過 はつぎのようである。

未溶解炭：炭酸ガス転化率 30\% で未溶解炭は約 $10 \%$ と なり石炭の約 $90 \%$ がすでに酸化分解を受けて低分子化 しており，炭酸ガス転化率 50\% では石炭の 98～99\% が

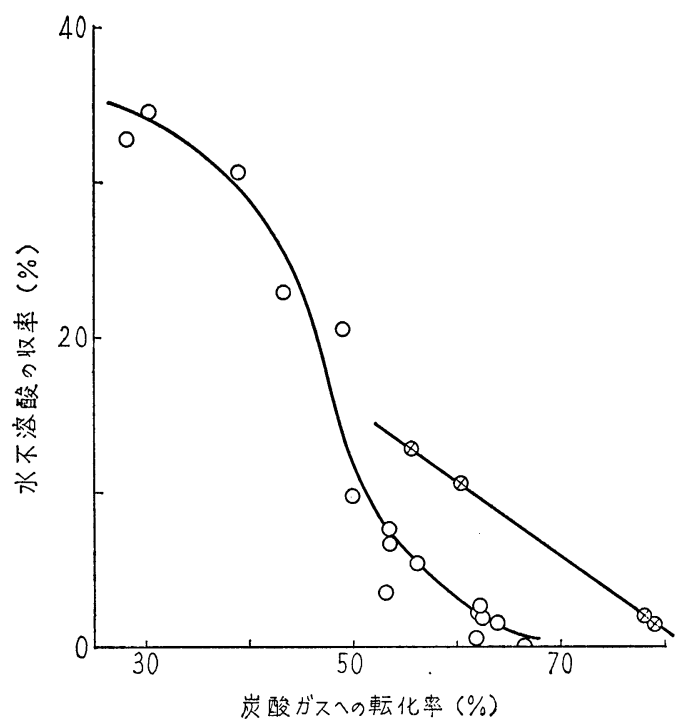

图 1 水不溶酸の収率

○ アルカリ十分

$\otimes$ アルカリ不足

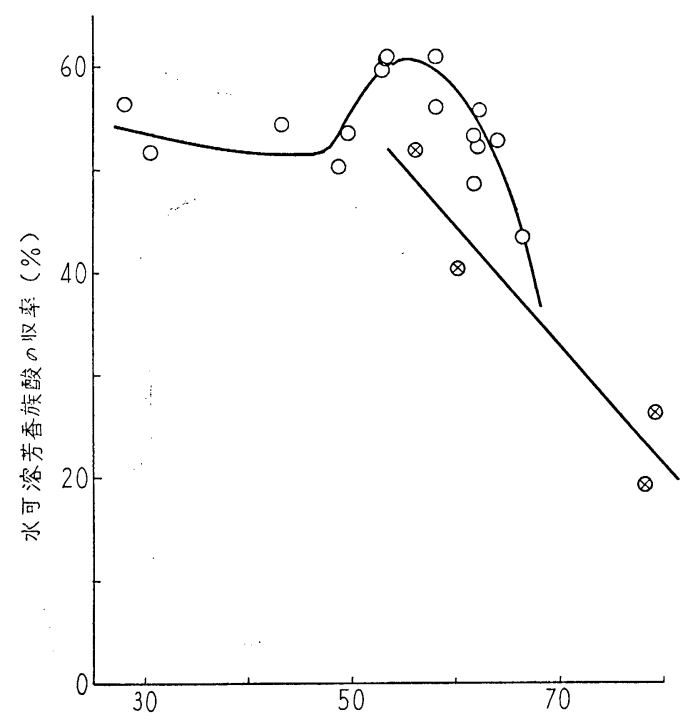

炭酸がスへの転化率(\%)

図 2 芳香族酸の収率

○ アルカリ十分

アルカリ不足

酸化分解を受けている。

水不溶酸: 石炭の一次酸化分解で得られる水不溶酸の収 率は炭酸ガス転化率 30\% で約 35\%，50\% で約 10\% と なり，生成した水不溶酸はひきつついて酸化分解を受け て低分子酸へ変化している。炭酸ガス転化率が 60〜65 \%になると水不溶酸はほとんど酸化分解を 受けてしま 
っている。

水可溶芳香族酸：水不溶酸の酸化分解によって生成する 水可溶芳香族酸の収率は炭酸ガス転化率 $30 \%$ で約 $53 \%$, 55 60\% で $61 \%$ に達したのち，さらに反応が進行する にしたがって水可溶芳香族酸は酸化分解を受け, 収率が 低下してくる。

シュウ酸：シュウ酸は炭酸ガス転化率 30〜 $50 \%$ の間は 約 $7 \%$ であったが，炭酸ガス転化率が $50 \%$ をこえると 14\%の収率を示したのち急激に低下している。

カセイソーダの添加量が少なくなると炭酸ガスの転化 率が同一でも水不溶酸の収率は大きく, 水可溶芳香族酸 およびシュウ酸の収率は低くなる傾向を示している。力 セイソーダの添加量が少ないと, 水不溶酸の酸化分解速 度にくらべて, 水可溶酸の酸化分解速度が速くなり, 水 可溶酸の収率が低下したものと考えられ，カセイソーダ の量は生成した酸の酸化分解に大きく影響している。

b. 炭酸ソーダ, 炭酸カリ 炭酸ソーダのような炭酸 アルカリを使用する場合にも添加量が少ないと反応速 度, 酸化生成物の収率はともに低下するが, 添加量を増 加させると酸化速度は速くなり, 酸化生成物の収率は増 加してカセイアルカリを使用した場合と同等あるいはそ れ以上の結果を得るようになる ${ }^{10)}$ 。また工業化における 問題に関しても，低温における炭酸ソーダの溶解度の小 さいことから回収はきわめて容易であり，反応装置の腐 食も比較的小さいなどの有利な点が考えられる。なほ, 炭酸ソーダを用いる場合には密閉状態で酸化を行なう方 法と生成する炭酸ガスを排除しながら定圧下に酸化を行 なう方法がある。

密閉状態で酸化反応を行なう場合は副生する炭酸ガス のため, 反応溶液を酸化に最適なアルカリ性に保つには 多量の炭酸ソーダを添加することが必要である。神谷 ${ }^{10)}$ はカセイソーダを用いた場合の水可溶芳香族酸の収率が 最高になる反応条件（酸素初圧 $25 \sim 30 \mathrm{~kg} / \mathrm{cm}^{2}$, 反応温 度 $250^{\circ} \mathrm{C}$ にて 90 分あるいは反応温度 $270^{\circ} \mathrm{C}$ にて 10 分） で鹿町炭を炭酸ソーダ水溶液中で酸化して炭酸ソーダの 添加量が石炭の 6 倍以上になるとカセイソーダを用いた 場合の水可溶芳香族酸の収率と同様の収率で水可溶芳香 族酸が得られることを報告している（図 3，4 参照）。

定圧下に酸素を導入し，生成する炭酸ガスを連続的に 除去して酸化を行ならならば炭酸ソーダの添加量が少量 でも反応溶液のアルカリ性をかなり高く保つことができ

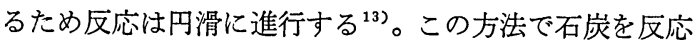
温度 $270 \sim 2^{\circ} \mathrm{C}$, 反応時間 $120 \mathrm{~min}$ で酸化したときの結 果の一例を表 1 に示めす。炭酸ソーダの添加量が無水無 灰炭と同量の場合は水不溶酸の収率が高く, 酸化分解速

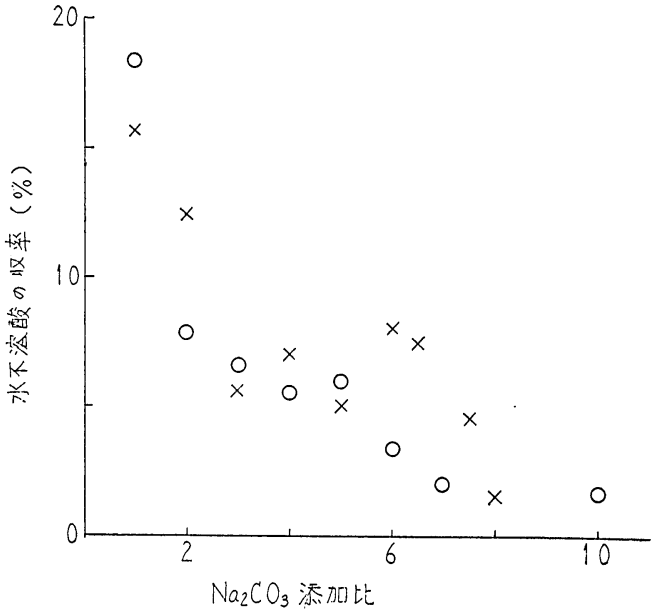

図 3 水不溶酸の収率と炭酸ソーダ添扣比

○ $250^{\circ} \mathrm{C}-90 \mathrm{~min}$

$\times \quad 270^{\circ} \mathrm{C}-10 \mathrm{~min}$

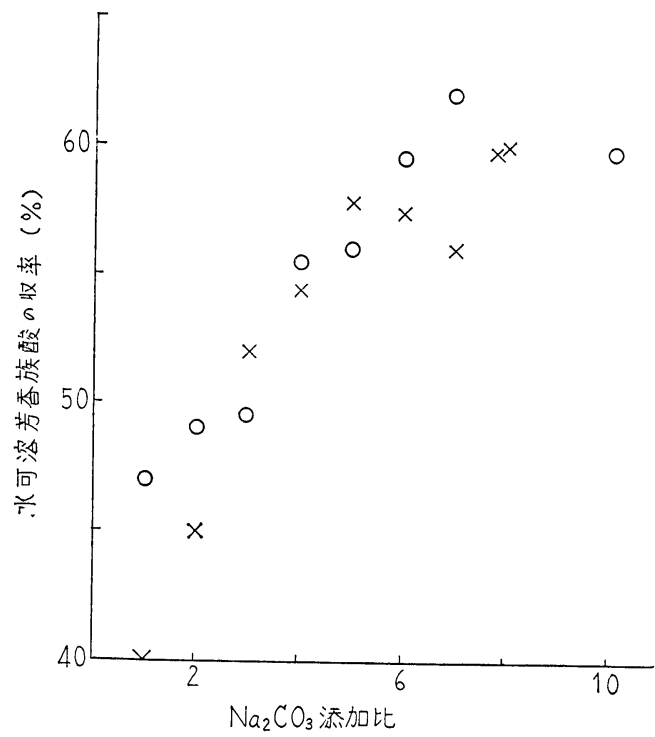

図 4 水可溶芳香族酸の収率と炭酸ソーダ添加比

$\bigcirc 250^{\circ} \mathrm{C}-90 \mathrm{~min}$
$\times \quad 270^{\circ} \mathrm{C}-10 \mathrm{~min}$

表 1

\begin{tabular}{c|r|r}
\hline $\begin{array}{c}\text { 炭酸ソーダ 添加量 } \\
\text { (石炭重量に対して) }\end{array}$ & \multicolumn{2}{|c}{ 酸化生成物（無水無灰炭 wt\%） } \\
\cline { 2 - 3 } 水 不溶 酸 & 水可溶芳香族酸 \\
\hline 1 倍 & 8.2 & 48.9 \\
2 倍 & 1.8 & 61.2 \\
3 倍 & 1.4 & 58.7 \\
\hline
\end{tabular}

度は遅いが, 炭酸ソーダの添加量が石炭の 2 倍になると 
水不溶酸 $1.8 \%$, 水可溶芳香族酸 $61.2 \%$ となり, カセ イソーダを 3 倍量使用した場合，あるいは密閉状態で炭 酸ソーダを 6 倍量使用した場合と同量の水可溶芳香族酸 を得ることが出来る。

炭酸カリ ${ }^{14) を}$ 用いると反応速度は炭酸ソーダを用いた 場合々同様で，3倍量の炭酸カリを添加して水可溶芳香 族酸の生成量は極大となる。水可溶芳香族酸の収率は $65 \%$ に達し，炭酸ソーダの場合より幾分高い。

c. 水酸化カルシウム カセイソーダや炭酸ソーダのか わりに安価な水酸化カルシウムを使用できるかどうかと いらことは工業的に興味ある問題である。Fischer ${ }^{5)} ら$ は水酸化カルシウムを用いて石炭を空気酸化している が，生成物の収量はきわめて低い。Howard ${ }^{6)}$ はカセイ カリを使用して石炭を酸素酸化する場合, カセイカリの 約 $80 \%$ を水酸化カルシウムで代替できると述べている。 水酸化カルシウムのみでは水溶液中アルカリ濃度が小さ いなどのため石炭の酸化反応が円滑に進行しないものと 考えられる。神谷 ${ }^{15)}$ も水酸化カルシウム 3.7 倍量を用い て酸素初圧 $30 \mathrm{~kg} / \mathrm{cm}^{2}, 260^{\circ} \mathrm{C}, 60 \mathrm{~min}$ の条件で石炭の 酸化を試みているが反応はほとんど進行していない。

\section{表 2}

反応条件 $260^{\circ} \mathrm{C}-60 \mathrm{~min}$.

中性塩の添加比 $\mathrm{NaCl} 1.5, \mathrm{Na}_{2} \mathrm{SO}_{4} 1.8$

\begin{tabular}{|c|c|c|c|c|c|}
\hline ᄀ & カ & リ & 生 & 成 & $(\mathrm{wt} \%)$ \\
\hline $\begin{array}{l}\mathrm{Na}_{2} \mathrm{CO}_{3} \\
\text { 添 加 比 }\end{array}$ & $\begin{array}{l}\text { 中 性塩 } \\
\text { 種 } \\
\end{array}$ & $\begin{array}{l}\mathrm{Ca}(\mathrm{OH})_{2} \\
\text { 添 加 比 }\end{array}$ & $\begin{array}{l}\text { 水可 溶 } \\
\text { 芳香族 }\end{array}$ & 水不溶酸 & 未溶解炭 \\
\hline 0 & - & 3.7 & 1.8 & - & - \\
\hline 11 & $\mathrm{NaCl}$ & " & 4.8 & 一 & - \\
\hline "I & $\mathrm{Na}_{2} \mathrm{SO}_{4}$ & " & 38.0 & 1.3 & 28.3 \\
\hline 0.25 & - & "I & 14.0 & - & - \\
\hline " & $\mathrm{NaCl}$ & " & 41.7 & 8.6 & 14.6 \\
\hline 0.5 & - & " & 43.3 & 14.5 & 11.1 \\
\hline " & $\mathrm{NaCl}$ & " & 49.6 & 5.6 & 10.6 \\
\hline " & $\mathrm{Na}_{2} \mathrm{SO}_{4}$ & "I & 48.6 & 2.3 & 10.2 \\
\hline
\end{tabular}

表 3

\begin{tabular}{|c|c|c|c|c|c|c|c|c|}
\hline & \multirow{3}{*}{ 炭 } & \multirow{2}{*}{\multicolumn{2}{|c|}{ 種 }} & \multicolumn{3}{|c|}{ 酸 化 条 件 } & \multicolumn{2}{|c|}{ 生成物収率(\%) } \\
\hline & & & & \multirow{2}{*}{$\begin{array}{c}\text { 温 度 } \\
{ }^{\circ} \mathrm{C}\end{array}$} & \multirow{2}{*}{$\begin{array}{c}\text { 時 間 } \\
\text { min }\end{array}$} & \multirow{2}{*}{$\begin{array}{l}\text { 生力 } \\
\mathrm{kg} / \mathrm{cm}^{2}\end{array}$} & \multirow{2}{*}{ 水不溶酸 } & \multirow{2}{*}{$\begin{array}{l}\text { 水可 溶 } \\
\text { 芳香族酸 }\end{array}$} \\
\hline & & $\mathrm{C} \%$ & $\mathrm{H} \%$ & & & & & \\
\hline 鹿 & 町 & 87.3 & 5.1 & 270 & 120 & 70 & 3.9 & 60.8 \\
\hline 鹿 & 町 & 87.3 & 5.1 & 250 & " & 60 & 25.3 & 51.6 \\
\hline 夕 & 張 & 84.0 & 6.3 & " & "I & " & 0.8 & 46.4 \\
\hline 美 & 唄 & 77.8 & 5.2 & " & " & " & $<0.1$ & 37.4 \\
\hline & 曹炭 & 59.8 & 5.7 & "I & " & 11 & $<0.1$ & 24.5 \\
\hline 夕 & 張 & 84.0 & 6.3 & 260 & 60 & 65 & 5.5 & 53.6 \\
\hline
\end{tabular}

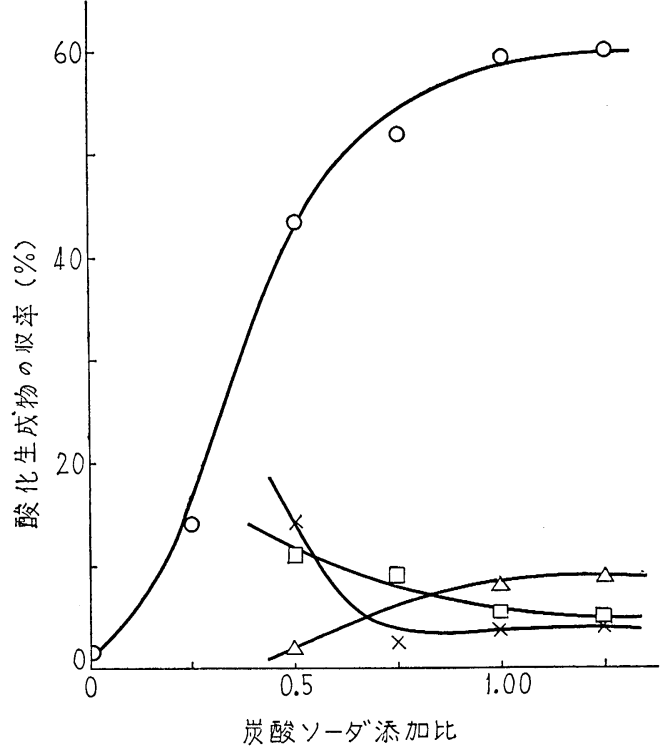

図 5 酸化生成物の収率と水酸化カルシウム 炭酸ソーダ

$$
\begin{array}{ll}
\bigcirc & \text { 水可溶芳香族酸 } \\
\times & \text { 水不溶酸 } \\
\triangle & \text { Vェ兄酸 } \\
\square & \text { 末溶解炭 }
\end{array}
$$

\section{d. 水酸化カルシゥムと炭酸ソータ}

の混合 水酸化カルシウムと炭酸ソー ダを添加して石炭を酸素酸化すると良 好な結果を得る ${ }^{15)}$ 。水酸化カルシウム の添加量 3.7 倍量, 炭酸ソーダの添加 量 1 倍量で，水可溶芳香族酸の収量は 約 $60 \%$ に達し，炭酸ソーダを 3 倍量 添加した場合と同様の収率を得ること ができる。炭酸ソーダの添加量が増す にしたがって反応速度は速くなる（図 5 参照)。

e. 中性塩の効果 アルカリに塩化 ナトリウム，硫酸ナトリウムなどの中 性塩を添加して酸化した場合中性塩の 効果が認められている ${ }^{15)}$ (表 2 参照)。

\section{ii. 酸化生成物の収率之炭種, 前処} 理

a. 炭種 炭化度の高い石炭ほど反 応性は低下するが，芳香族酸の収率は 増加する ${ }^{7)}$ 。神谷 ${ }^{11)}$ も種々の石炭をア ルカリ酸素酸化して鹿町炭で好結果を 得ている(表 3 参照)。

b. 空気酸化前処理 石炭の酸化に 
先だち石炭に何らかの前処理を行なって酸化反応に適し た石炭とし，これを酸化することは炭種が生成物の収率 に影響することから，石炭の酸化生成物の収率を向上さ せるに有効な一手段と考えられる。たとえば石炭を空気

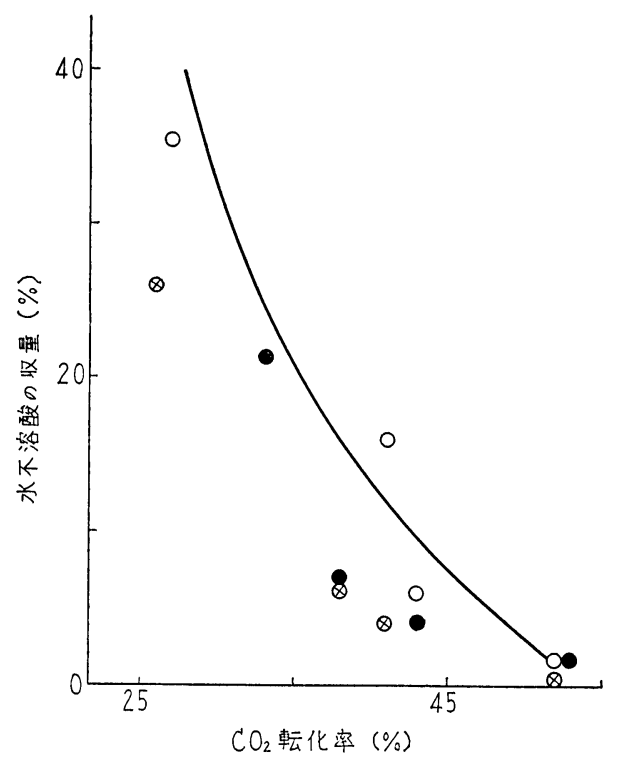

图 6

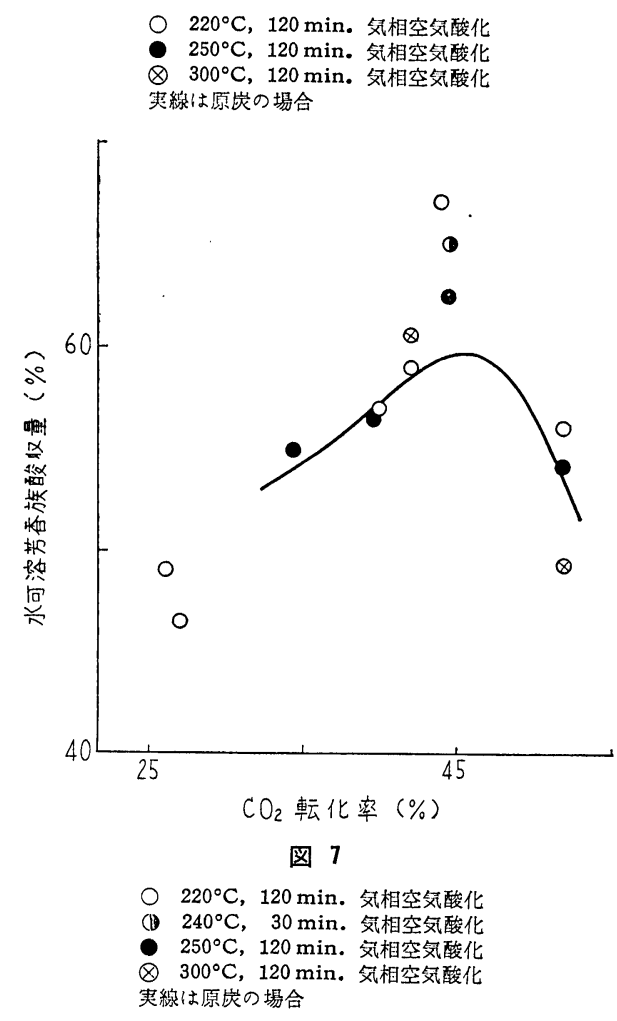

酸化してから液相酸化を行ならと反応速度がいちじるし く増加すること ${ }^{17 \sim 199}$ が知られている。神谷 ${ }^{20)}$ は石炭を流 動層反応装置で $200 ， 250 ， 300^{\circ} \mathrm{C}$ でそれぞれ $120 \mathrm{~min}$ 空 気酸化前処理を行ない, カセイソーダ水溶液中で 230 $270^{\circ} \mathrm{C}, 10 \sim 120 \min$ の反応条件で酸化を行ない, 末処 理炭に比べて前処理した石炭の水可溶芳香族酸の収率は 増加している(図 6，7）。

c. 低炭化度炭の乾留前処理 石炭を酸化して芳香族 カルボン酸類を好収率で得るには比較的炭化度の進んで いるレキ青炭が最も適しているが，炭化度の低い石炭を 原料とする場合は乾留などの前処理を行なって炭化度を 高めたらえで酸化を行ならことが適当と考えられる。神 谷 ${ }^{211}$ は低炭化度の石炭を乾留したのち, アルカリ酸素酸. 化を行なって乾留条件と酸化生成物の收率の関係を検討 している。その結果によると 550 $780^{\circ} \mathrm{C}$ にて低度の乾 留を行なった石炭（C％=80 91\%）をカセイソーダあ るいは炭酸ソーダ水溶液中で酸素初圧 $30 \mathrm{~kg} / \mathrm{cm}^{2}$ で酸 化を行ない, 反応温度 $250 \sim 260^{\circ} \mathrm{C}$ で水可溶芳香族酸を 約 55\% の収率で得ている。乾留温度が高くなると石炭 の酸化反応性が減退し酸化反応後に有機残留物量が増加; してくる(図 8 参照)。

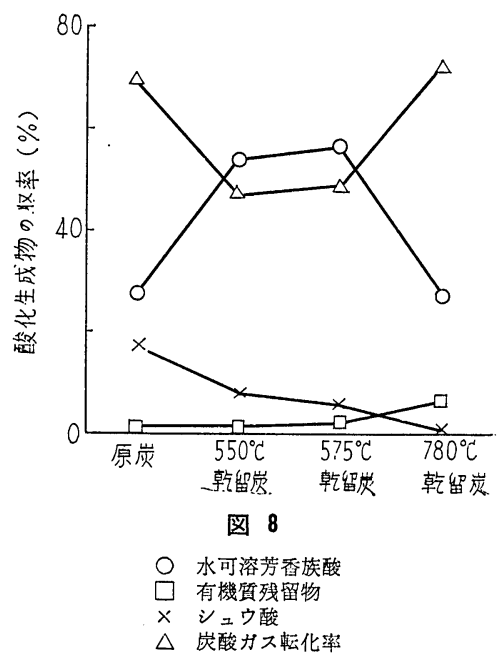

iii. 水不溶酸, 水可溶芳香族酸の泾質, 組成

a. 水不溶酸の性質 水不溶酸は石炭の一次酸化生成 物でアルカリ可溶, 水に不溶のかなり高分子量の酸であ, る。水不溶酸の性質は石炭の酸化条件によって異なり, 酸化反応が進行するにつれて水不溶酸の中和当量が減少 する傾向がみられ，バリウム塩可溶分が増加する ${ }^{22)}$ 。色 調もまた黒カツ色から黄カツ色となり，母核構造の縮少 したことを示している。 水不溶酸はさらに酸化分解を受けて水可溶芳香族酸を 
生成する。たとえば水不溶酸を $10 \%$ カセイソーダ水溶 液中で, 酸素初圧 $23 \mathrm{~kg} / \mathrm{cm}^{2}, 260^{\circ} \mathrm{C}$ にて $60 \mathrm{~min}$ 酸化 して, 水可溶芳香族酸を $49 \%$ ，シュウ酸を $5.6 \%$ の収 率で得ている ${ }^{22)}$ 。

b. 水可溶芳香族酸の性質, 組成 水可溶芳香族酸は 水不溶酸の酸化分解により生成する水可溶, メチルエチ

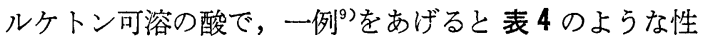
質のものである。

\section{表 4}

\begin{tabular}{|c|c|}
\hline カルボキシル基当量 & 89 \\
\hline フェノール 基 当量 & 1,500 \\
\hline $\mathrm{C} \%$ & 54.2 \\
\hline $\mathrm{H} \%$ & 4.2 \\
\hline 量 & 230 \\
\hline メトキ & 0.3 \\
\hline
\end{tabular}

石炭を酸化して約 60\% の収率で得られる水可溶芳香 族酸は 30〜 40\% のベンゼンカルボン酸を含み，他はほ とんどが芳香族カルボン酸である。ベンゼンカルボン酸 の無水無灰炭に対する収率はカセイソーダの場合は 16 $\sim 20 \%$, 炭酸ソーダの場合 $26 \%{ }^{24)}$ で, 炭酸ソーダの方 がすぐれている。ベンゼンカルボン酸の主なものはベ ンゼントリカルボン酸とベンゼンテトラカルボン酸であ る。ベンゼンジカルボン酸の含有量が小さいのは, 後述す るようにベンゼンジカルボン酸は酸化条件において不安 定で分解するためと考えられる。ベンゼンカルボン酸の

表 5

アルカリニカセイソーダ

\begin{tabular}{|c|c|c|}
\hline ベンゼンカルボン酸 & (水組溶芳香成 & $\begin{array}{c}(w t \%) \\
\text { 酸に対して) }\end{array}$ \\
\hline ベンゼンジカルボン酸 & 8.3 & \\
\hline フルタ酸 & & 6.3 \\
\hline イソフタル酸 & & 1.4 \\
\hline テレフタル酸 & & 0.6 \\
\hline ベンゼントリカルボン酸 & 14.4 & \\
\hline トリメリット酸 & & $\sim 9.4$ \\
\hline ヘミメリット酸 & & $\sim 3.6$ \\
\hline トリメシン酸 & & $\sim 1.4$ \\
\hline ベンゼンテトラカルボン酸 & 7.8 & \\
\hline ピロメリット酸 & & (大部分) \\
\hline メロファン酸 & & (一部分) \\
\hline ベンゼンペンタカルボン酸 & 1.2 & \\
\hline ベンゼンヘキサカルボン酸 & 1.0 & \\
\hline ナフタリントリカルボン酸 & 2.6 & \\
\hline 合 & 35.3 & \\
\hline
\end{tabular}

らちジー,トリ-, テトラカルボン酸の比率はカセイソー ダの場合は $1: 1.5 \sim 1.7: 1 \sim 0.9$, 炭酸ソーダの場合は $1: 2: 2$ となり, 炭酸ソーダの場合は硝酸酸化の場合 ${ }^{192}$ と一致している (表 5,6 参照)。

\section{表 6}

アルカリ $=$ 炭酸ソーダ

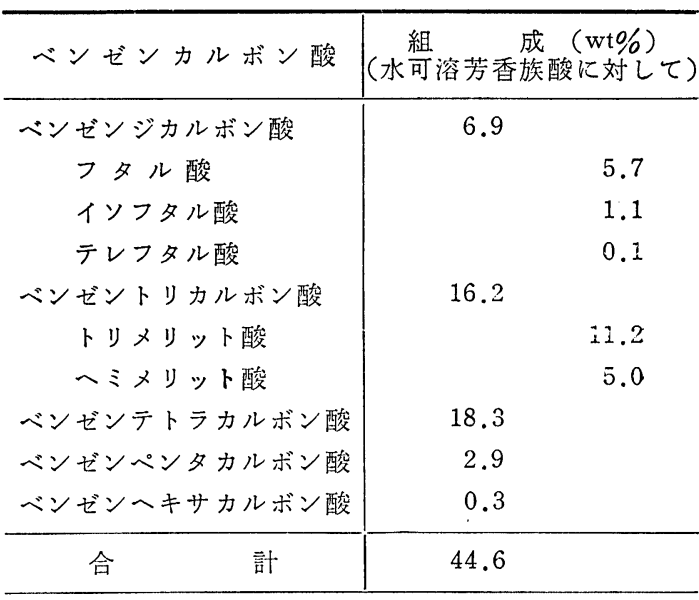

ベンゼンカルボン酸の酸化反応に対する安定性は石炭 酸化によって得られるベンゼンカルボン酸の収率および その組成に関係してくる。神谷 ${ }^{11}$ らはベンゼンカルボン 酸を石炭酸化条件で酸化してベンゼンカルボン酸の安定 性を検討している (表 7 参照)。それによるとフタル酸

表 7

\begin{tabular}{|c|c|c|}
\hline カル ボ ン 酸 & アルカリ & 未反応酸 $(\%)$ \\
\hline フタル酸 & $\mathrm{NaOH}$ & 86.2 \\
\hline フタル酸 & $\mathrm{Na}_{2} \mathrm{CO}_{3}$ & 47.3 \\
\hline イソフタル酸 & " & 48.3 \\
\hline テレフタル酸 & " & 49.3 \\
\hline ベンゼントリカルボン酸(1) & " & 82.8 \\
\hline ベンゼンテトラカルボン酸(2) & " & 71.4 \\
\hline コハク酸 & "I & 6.5 \\
\hline
\end{tabular}

（1）トリメリット酸とへミメリット酸の混合物

（2）プレニト酸とピロメリット酸の混合物

は水酸化ナトリウム水溶液中では比較的安定であるが炭 酸ナトリウム水溶液中ではかなり分解する。これに対し てベンゼントリカルボン酸およびベンゼンテトラカルボ ン酸類は炭酸ナトリウム水溶液中でも比較的安定である が，コハク酸のような脂肪族酸は容易に酸化分解を受け るよらである。

Germain $^{8)}$ らは石炭のアルカリ酸素酸化によって得ら れたベンゼンカルボン酸類をさらに石炭と同一の反忘条 件のもとに反応させてベンゼンカルボン酸類の酸化反応 
時における安定性を検討している。それによるとベンゼ ンカルボン酸類の酸化反応時における分解はかなり激し 、ものであり，かなり多量のベンゼンカルボン酸が炭酸 ガス，シュウ酸に分解している。したがって石炭の酸化 によりベンゼンカルボン酸を好収率で得るには反応条件 の選択，特に反応時間について十分注意する必要があ る。

iv. 酸化生成物の変成 石炭の酸化生成物は複雑な混 合物でその成分に分離することは困難である。石炭の酸 化生成物の有効な利用を考えるらえにも生成物中の成分 の数は少なく，容易に単離できることが望ましい。この ために酸化生成物を脱炭酸などの処理を行なって変成す ることが試みられている。

a. 脱炭酸 酸化生成物を一部脱炭酸してより簡単な 組成にして生成物を取り出す試みが行なわれた ${ }^{25)}$ 。酸化 生成物を硫酸銅を添加して $300 \sim 330^{\circ} \mathrm{C}$ に $30 \sim 60 \mathrm{~min}$ 加熱して脱炭酸処理を行ならと水可溶芳香族酸の収率は 減少して 10 13\% となり, 水不溶酸は増加して $30 \%$ 近 くに達する。同様な 結果は硫酸銅を 添加せず $330^{\circ} \mathrm{C}$ に 30 min 保っても得られる。また，酸化前に硫酸銅を添加 して扔いて, 酸化後 $300^{\circ} \mathrm{C}$ に $30 \mathrm{~min}$ 間脱炭酸処理を

\section{表 8}

\begin{tabular}{|c|c|c|c|c|c|c|}
\hline 脱 & 炭 & & 条 & 件 & 生 成 & 物 $(\%)$ \\
\hline $\begin{array}{c}\text { 温 } \\
\left({ }^{\circ} \mathrm{C}\right)\end{array}$ & $\begin{array}{l}\text { 時 荫 } \\
(\min \end{array}$ & & $\begin{array}{l}\mathrm{CuSO}_{4} \\
\text { 添加量 }\end{array}$ & $\begin{array}{l}.5 \mathrm{H}_{2} \mathrm{O} \\
\text { 量 }(\%)\end{array}$ & 水不溶酸 & $\begin{array}{l}\text { 水 可 溶 } \\
\text { 芳香族酸 }\end{array}$ \\
\hline 300 & 3 & & & - & 4.5 & 55.0 \\
\hline 328 & 3 & & & - & 30.1 & 12.8 \\
\hline 300 & 3 & & & 0.3 & 8.0 & \\
\hline 300 & 3 & & & 3.0 & 27.8 & \\
\hline 300 & 3 & & & 30.0 & 27.0 & 9.0 \\
\hline
\end{tabular}

表 9

\begin{tabular}{c|c}
\hline \multicolumn{1}{c|}{ 生成 } & $\begin{array}{c}\text { 收 } \\
\text { (無水灰炭基準 wi } \% \text { ) }\end{array}$ \\
\hline 水不溶酸 & 30 \\
テレフタル酸 & 3.5 \\
インフタル酸 & 6.3 \\
$2 \sim 3$ 環を有する芳香族 & $\sim 5$ \\
カルボン酸 & \\
高分子量酸 & $\sim 2$ \\
その他極性の強い化合物 & $\sim 13$ \\
水可溶芳香族酸 & 14 \\
安息 香 酸 & 2.8 \\
フタル ル 酸 & 3.1 \\
トリメシン酸 & 1.2 \\
その他極性の強い化合物 & $\sim 7$ \\
\hline
\end{tabular}

行なっても得られる (表 8 参照)。

- 脱炭酸生成物の水不溶酸, 水可溶芳香族酸の組成は表 9のように推定されている ${ }^{26)}$ 。

b. 水可溶芳香族酸塩の熱処理 石炭の酸化によって 得られる水可溶芳香族酸は約 $40 \%$ がベンゼンカルボン 酸で，その主成分はベンゼントリおよびテトラカルボン 酸である。この水可溶芳香酸にヘンケル法を適用して水 可溶芳香族酸のカリウム塩を $400 \sim 450^{\circ} \mathrm{C}$ に加熱してべ ンゼンカルボン酸をテレフタル酸に変成して取り出そう とする試みがなされた ${ }^{27)}$ 。その結果, 反忘温度および時 間は $400 \sim 430^{\circ} \mathrm{C}, 1 \sim 4 \mathrm{hr}$ が適当であり，カリウム塩の 場合はテレフタル酸への転位反応が加わるため, テレフ タル酸のイソフタル酸に対する比率は大きくなるがナト リウム塩の場合は脱炭反応のみが考えられ，テレフタル 酸のイソフタル酸に対する比率は $1: 2$ で一定であり, 安息香酸の収率が増加する。水可溶芳香族酸は 1 分子あ たり平均 3.2 のカルボキシル基を有しているが，これの 中和率が高い程テレフタル酸とイソフタル酸の収率は高 くなっており，ベンゼンジカルボン酸の収率活水可溶芳 香族酸に対して $22 \sim 24 \%$ で，テレフタル酸の最高収率 は水可溶芳香族酸に対して約 $20 \%$ を得ている（表 10 参照)。

\section{表 10}

\begin{tabular}{l|r|r|r}
\hline アルカリの種類 & \multicolumn{1}{|c|}{$\mathrm{K}$} & $\mathrm{K}$ & $\mathrm{Na}$ \\
\hline 中 和 率 & $2 / 3.2$ & 1 & $2 / 3.2$ \\
$\mathrm{CdCl}_{2}$ 添加率 $(\%)$ & 0.1 & 0.1 & 0 \\
反応温度 $\left({ }^{\circ} \mathrm{C}\right)$ & 430 & 430 & 400 \\
反応時間 $(\mathrm{hr})$ & 1 & 4 & 3 \\
生 成 物 $(\%)$ & & & \\
水 不 溶 酸 & 32.7 & 53 & 33.4 \\
水可溶芳香族酸 & & & 28.3 \\
イソフタル酸 & 5.7 & 3.9 & 9.1 \\
テレフタル酸 & 14.9 & 19.6 & 4.5 \\
フタ ル 酸 & 1.2 & - & 3.3 \\
安 息 香 酸 & 0.1 & - & 3.0 \\
\hline
\end{tabular}

2. 石炭の硝酸酸化 石炭を工業的に酸化してベン ゼンカルボン酸を製造すを方法としてアルカリ酸素酸化 とともに硝酸酸化がある。硝酸酸化の場合はアルカリ酸 素酸化と異なりニトロ化物が副生してくるが，ベンゼン カルボン酸の収率, 組成はアルカリ酸素酸化の場合とほ ぼ同様である。硝酸酸化には常圧で還流下に加熱する方 法, 加圧下に加熱する方法, 酸素と共存させて酸化する 方法などがある。

i. 䢱流法 希硝酸で還流下に石炭を酸化するには長 
時間加熱することが必要で, Howard ${ }^{28)}$ らは $1 N$ の硝酸で還流下に加熱してフ ミン酸, 水可溶酸の収率を検討してい る。それによるとフミン酸は 2 日後に $78 \%$ の収率となり, 水可溶酸は 32 日に 33 34\% の収率に達している。水可溶 酸のなかにベンゼンペンタカルボン酸お よびメリット酸を確認している。

石炭を硝酸で還流下に加熱すると暗力 ツ色の硝酸不溶フミン酸を生成するが, さらに酸化を続けると硝酸可溶のフミン 酸となり，ついで水可溶酸を生成する。

石炭に対する硝酸の作用に関して Tadzhier ${ }^{29)}$ は $12 N$-硝酸で $65 \sim 70^{\circ} \mathrm{C}$ に て 10〜15 min 間石炭を処理し, 硝酸に よる石炭分解を $25 \sim 30 \%$ 過酸化水素処 理の場合と比較して, 硝酸による初期の 石炭分解は石炭中のエステル結合の加水 分解によりカルボキシル基を生成するこ とから始まることを推論している。また Kinney ${ }^{30)}$ らも石炭を $10 \sim 15^{\circ} \mathrm{C}$ の低温 で硝酸処理して石炭の重量増加を認め, 低温においては酸化反応はほとんど進行せず，もっぱら 硝酸の付加あるいはフェニールエーテル結合などの切 断, ニトロフェノール類の生成反応がおこっているもの と考えている。反応温度が $70 \sim 100^{\circ} \mathrm{C}$ に至ると石炭の分 解がおこりカルボキシル基をもった硝酸不溶, アルカリ 可溶のフミン酸を生成してくる。そして反応温度が 100 ${ }^{\circ} \mathrm{C}$ をこえると少量ながら硝酸可溶フミン酸とともに水 可溶酸および炭酸ガスを生成しはじめるといらことをの ベている。フミン酸の収率は $110^{\circ} \mathrm{C} に て 15 \mathrm{~min}$ 反応さ せたとき $77.5 \%$ の石炭中の炭素が硝酸不溶フミン酸と なり，1.3\%の炭素が硝酸可溶フミン酸となり, 合計 $78.8 \%$ の炭素収率でフミン酸が得られている。

Grosskinsky ${ }^{17)}$ は濃硝酸を用いて還流下に加熱して石 炭を酸化している。その結果によると生成する酸の約 40\% がベンゼンカルボン酸である。濃硝酸 (33\%) を用 いて $110^{\circ} \mathrm{C} に て 4 \mathrm{hr}$ 還流下に加熱して得た酸可溶性生 成物の組成を表 11 に示す。

硝酸不溶のフミン酸をさらに濃硝酸と還流下に加熱す ると硝酸可溶フミン酸, 水可溶酸を生成する ${ }^{30)}$ 。

すなわち, 酸化が進行するにつれて硝酸不溶フミン酸 は減少し, $3 \mathrm{hr}$ 後には約 $7 \%$ となり, 硝酸可溶フミン 酸および水可溶物となる。硝酸可溶フミン酸は炭素\%が 57.5\%でほぼ一定であり, 一般に石炭を酸化して得られ
表 11

\begin{tabular}{r|l}
\multicolumn{1}{c|}{$\begin{array}{c}\text { 組 } \\
(\%)\end{array}$} & \multicolumn{1}{c}{ 備 } \\
11.1 & ユハク酸・アジピン酸 \\
6.8 & フ タ ル 酸 \\
18.8 & トリメリット酸・ヘミメリット酸 \\
10.3 & ピロメリット酸・メロフフン酸 \\
3.4 & \\
20.5 & \\
29.1 &
\end{tabular}

表 12

\begin{tabular}{r|c}
$(\%)$ & \multicolumn{1}{c}{ 備 } \\
\hline 6.5 & エハク酸・グルタル酸・フジピン酸 \\
3.5 & フタル酸・イソフタル酸・テレフ \\
8.0 & タル酸 \\
7.0 & ト゚ロメリッット酸・ヘミメリット酸 \\
5.5 & \\
2.0 & \\
8.0 & \\
6.5 & \\
52.0 &
\end{tabular}

るフミン酸と同様のものと思われる。なお硝酸可溶フミ ン酸が水可溶物に酸化分解されるとき的 $20 \%$ の炭酸ガ スの発生をもともなっている。

ii. 加圧法 $5 \mathrm{~atm}$ 程度の圧力下に $150 \sim 160^{\circ} \mathrm{C}$ に保 って石炭を硝酸酸化するものである ${ }^{32)}$ 。

Benning ${ }^{18)}$ は 15〜35\% 硝酸を用いて 5 atm の加圧下 で $150 \sim 160^{\circ} \mathrm{C}$ に $2 \mathrm{hr}$ 保って石炭を酸化し, 酸可溶酸を 60〜75\% 収率で得ている。この酸化生成物の 組成を表 12 に示す。

石炭を硝酸 ( $d=1.15)$ で $4 \mathrm{~atm}$ の加圧下に連続的に 硝酸溶液を抜きだし，新しい硝酸を加えながら酸化する 方法 $^{33)}$ 女る。

コークスを用いれば 33\% 硝酸を用いて $10 \mathrm{~atm}$ の加圧 下に反応温度 $150^{\circ} \mathrm{C}$ で $4 \mathrm{hr}$ 反応させて $30 \%$ の収率でメ リット酸が得られる ${ }^{34)}$ 。メリット酸はまたコークスを $67 \%$ 硝酸で $48 \mathrm{hr}$ 還流下に加熱し, 得られる粗生成物を アルカリ処理し，メチルエチルケトン抽出してアンモニ ウム塩として取り出す方法 ${ }^{35)}$ ある。

iii. 酸素加圧法 石炭を硝酸で酸化するとき酸素を共 存させると硝酸量を減少出来ることが知られ ${ }^{28)}$, 石炭を 硝酸で還流下に酸化する場合にも空気を導入しながら行 なう方法 ${ }^{36)}$ が考えられている。

Howard $^{12)}$ は石炭の硝酸酸化を酸素加圧下で行ない, 
硝酸浱度, 反応温度, 反応時間, 酸素圧の効果について検 討している。石炭を硝酸で還流下に酸化する場合は濃硝 酸 $(16 \mathrm{~mol} / l)$ を只いると石炭の酸化速度はかなり速くな るが, 硝酸濼度が低い場合は酸素加圧下 $\left(400 \mathrm{lb} / \mathrm{in}^{2}\right)$ に おいても反応温度 $110^{\circ} \mathrm{C}$ においては石炭の酸化速度は非 常に遅い。しかし反応温度を $190^{\circ} \mathrm{C}$ に上昇すると硝酸濃 度 $1 \sim 2 \mathrm{~mol} / l$ にて目的とする水可溶酸の収率は極大を 示し, 酸化速度も速くなる (図9参照)。このように反

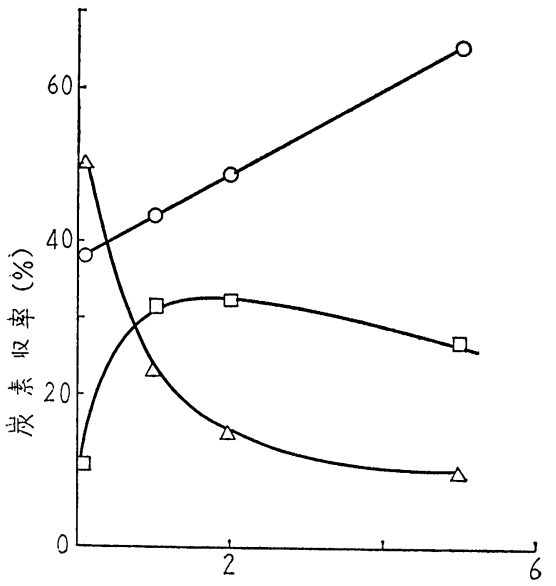

硝酸濃度 (M/e)

図 9

(反応条件 $190^{\circ} \mathrm{C}-24 \mathrm{hr}$ )

$$
\begin{aligned}
& \text { ○...炭酸出 ス } \\
& \triangle \cdots \cdots \text { 水不溶 酸 }
\end{aligned}
$$

㐫温度を上昇すると硝酸渻度の効果を補って酸化速度は 速くなる。しかし目的とする水可溶物の得量は反応条件 が過激となると酸化がさらに僬行するため減少し, 極大 値を示すようになる。

硝酸浱度 $4.5 \mathrm{~mol} / l$ で $4 \mathrm{hr}$ 石炭を酸化するときは反 疬温度 $170 \sim 185^{\circ} \mathrm{C}$ にて水可溶酸の収率は極大となり, これより高温では生成した水可溶酸の酸化反応が相対的 に速くなると考えられる。また反応時間も $4 \sim 8 \mathrm{hr}$ が最 適であり, 以後は水可溶酸の収率法減少する。

目的とする水可溶酸の収率は約 $40 \%$ で, その平均分 子量は 245 , 酸当量 94 であり,平均してベンゼン核に結 合しているカルボキシル基数は 2.6 である。アルカリ酸 素酸化による水可溶酸と比較するとベンゼン核に結合し ているカルボキシル基の数は幾分少ない（表 13 参照)。

アルカリ酸素酸化においては多量のアルカリ（石炭量 の約 3 倍) を必要とし, $270^{\circ} \mathrm{C}, 1,000 \mathrm{lb} / \mathrm{in}^{2}$ の高温, 高 圧を必要とする。また後処理においてはアルカリ中和の ため多嘼の酸を必要とする。これに対して硝酸酸化によ

\begin{tabular}{|c|c|c|}
\hline & 硝 酸 酸 化 & アルカリ酸菜酸化 \\
\hline 元菜組成 (\%) & & \\
\hline $\mathrm{C}$ & 47.21 & 54.3 \\
\hline $\mathrm{H}$ & 3.55 & 2.9 \\
\hline $\mathrm{N}$ & 4.43 & 0.1 \\
\hline $\mathrm{S}$ & & 0.4 \\
\hline $\mathrm{O}$ & 44.81 & 42.3 \\
\hline 子 量 & 245 & 265 \\
\hline カルボキシル基当量 & 94 & 83 \\
\hline カルボキシル 基数 & 2.6 & 3.2 \\
\hline
\end{tabular}

表 13

る方法ではそれ程の高温, 高圧を必要としない。しかし ながら硝酸の回収, 装置の腐食の問題がある。また生成 物中より窒素含有物の分離も問題となる。

iv. 石炭の前処理 Grosskinsky ${ }^{17)}$ は還流法による石 炭の硝酸酸化に先だち, 空気酸化前処理を行なうと酸化 速度が速くなることを認めている。

酸素やイオウの含有量の多い石炭 ${ }^{37)}$ や揮発分の多、石

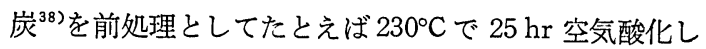
たのち, 硝酸酸化してベンゼンカルボン酸を好收率で得 ている。前処理として石炭を空気酸化して良好な結果を 得るのは $230^{\circ} \mathrm{C}$ 前後で石炭中の $-\mathrm{CH}_{2}-$ を含む系が酸化 されることによるものと考えられている ${ }^{39}$ 。

Jüttner ${ }^{19)}$ は石炭を硝酸で加圧下に酸化するとき前処

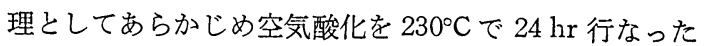
ときの效果を検討している。それによると，空気酸化を 前処理として行なうと生成酸中の高分子墨酸の収率は減 少し, ベンゼンカルボン酸, ピクリン酸の収率は増加す る。

空気酸化前処理の他に $180^{\circ} \mathrm{C}$ で $1 \mathrm{hr}$ 硫酸で処理する 方法 ${ }^{40)}$ ある。

\section{III. 酸化生成物の分離}

酸化生成物より各成分を分離するにはメチルエステル にして減圧蒸留する方法 ${ }^{1,23,13,17,46}$ が比較的容易であり，

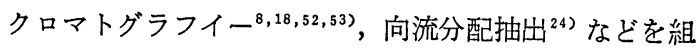
合せて分離, 確認されている。その他酸化生成物よりべ ンゼンカルボン酸を分離するためには硫酸処理 ${ }^{45,19,44)}$ し て他の不安定成分を重合させて除去したり, 水溶液の加 熱 ${ }^{43,42,41,19)}$ ，有機溶剤による抽出 ${ }^{47}$ などの方法もある。 水可溶酸からエーテル・ペンタン ${ }^{9,48)}$, アセトン・ベン ゼン ${ }^{48)}$, メチルエチルケトン・四塩化炭素 ${ }^{49}$ などの溶剤 を用いて再沈殿法による分㕍や水溶液の $\mathrm{pH}$ を変えて抽 出寸る方法 ${ }^{49}$ も試みられた。酸化生成物中のフタル酸な 


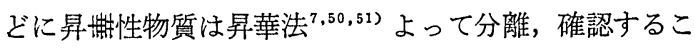
ともでき，バリウム塩などの溶解性の相異を利用 ${ }^{13,23,48)}$ し、て分離, 確認することもできる。

\section{IV. 石炭の酸化によらないベンゼンポ リカルボン酸類の合成}

上記のベンゼンカルボン酸は石炭の酸化以外にたとえ ばアルキルベンゼン，クロルメチル化アルキルベンゼン などの酸化によっても容易に合成することができる。筆

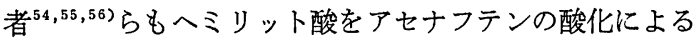
方法，メタキシレンのクロルメチル化物の酸化による方 法, トリメシン酸をメシチレンの酸化による方法, ピロ メリット酸をメタキシレンのジクロルメチル化物の酸化 による方法, ベンゼンペンタカルボン酸はメシチレンの ジクロルメチル化物の酸化による方法などによって合成 した。

\section{V. 石炭酸化生成物の利用}

石炭をアルカリ酸素酸化すると水可溶芳香族酸がほぼ 60\% の収率で得られる。水可溶芳香族酸の約 40\% はべ ンゼンカルボン酸類であり，その主成分はベンゼントリ カルボン酸およびベンゼンテトラカルボン酸であるが 12 種類の ベンゼンポリカルボン酸のほとんどすべてが 存在する。他の酸もほとんど芳香族酸である。石炭を硝 酸酸化を行なってもほぼ同様の組成の酸化生成物を得 る。これら石炭の酸化生成物の用途を開発することは重 要なことであり，またいろいろな面で興味ある用途が開 発されている。Dow Chemical Co. では石炭のアルカリ 酸素酸化にて得られる水可溶芳香族酸を coal acid と称 してその用途開発につとめている。coal acid は平均分 子量 270 , 当量 82 の芳香族酸で一分子当り平均 3.3 個の カルボキシル基をもつもので主としてベンゼン ポリカルボン酸よりなる。このような性質をも つ水可芳香族酸はしたがって多官能基性であ り, 多価アルコール, エポキシ化合物, ポリアミ ンなどと反応して樹脂化させることができる。

その他ベンゼンポリカルボン酸を原料にして 脱炭酸, 熱転位を行なってテレフタル酸を得る 方法などがある。

1. 安息香酸安息香酸は従来はナトリウ 厶塩が食品保存剤, 抗カビ剤として使用される ほか, 可塑剤, 医薬用いられていた。また製法 も塩化ベンゾイルの加水分解，フタル酸の脱炭

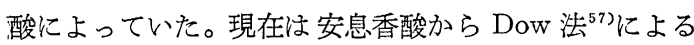

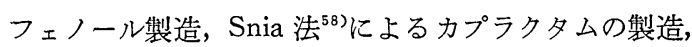

ヘンケル法 ${ }^{59}$ によるテレフタル酸の製造などの安息香酸 用途が開発されている。

i. 安息香酸からフェノールの合成 安息香酸より フェノールを合成する方法 ${ }^{57)}$ は Dow Chemical 社と California Research Co. により開発されたもので安息 香酸, 安息香酸銅, 酸化マグネシウムの混合物に約 230 ${ }^{\circ} \mathrm{C}$ で空気と水蒸気をふき込んで反応させ, 生成フェノー ルを留出させるものであり, 収率約 $80 \%$ である。この 反応は Kaeding ${ }^{60)}$ らによるとつぎのように進むものと 考えられている。

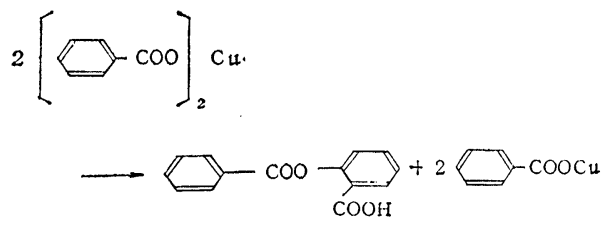

2

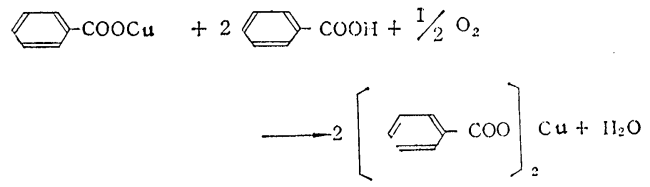

$\square+\mathrm{COO}-\mathrm{COOH}_{2} \mathrm{O}$
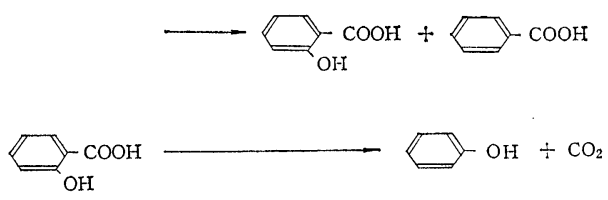

$\mathrm{Schoo}^{61)}$ は $\mathrm{C}^{14}$ を用いて $-\mathrm{OH}$ 基は $-\mathrm{COOH}$ 基に対して oー位に導入されることを証明した。また加藤 ${ }^{62}$ らはつぎ のような機構を推定している。

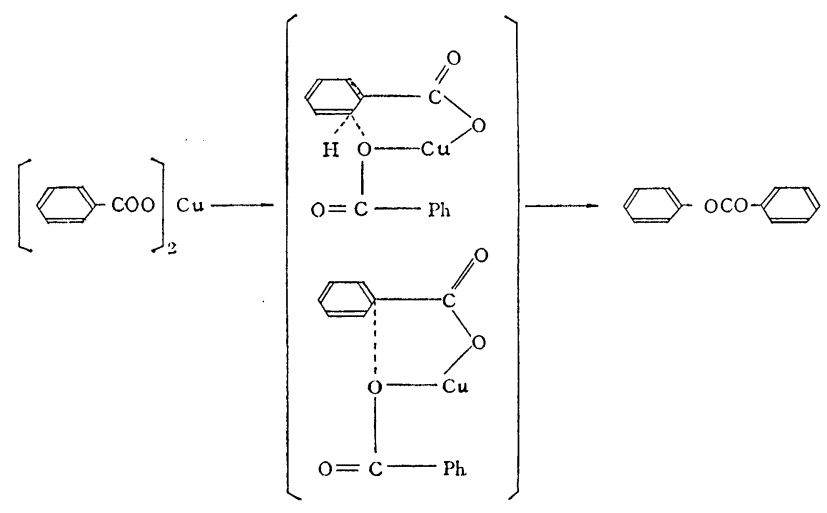

ii. 安息香酸から $\epsilon$-カプロラクタムの合成 安息香 酸からカプロラてタムを合成する Snia 法 $^{58}$ は最近話題 
となった。

$$
\text { = }
$$

この方法はへキサヒドロ安息香酸からカプロラクタム へは一段で行なうものであり, カプロラクタムの収率は 90\% 程度である。またこの方法はへキサヒドロ安息香 酸以外に

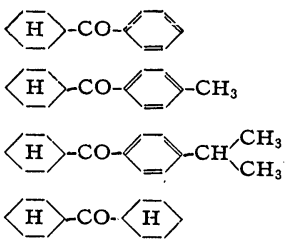

などを原料としてもニトロシル硫酸と反応してカプロラ クタムを得ることができる。たとえばつぎの過程による とカプロラクタムと同時にテレフタル酸む得られる。
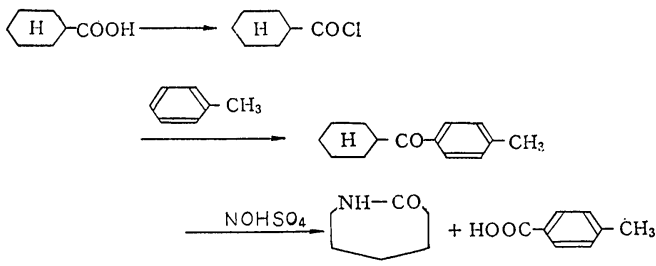

HOOC- $\square-\mathrm{CH}_{3}$ 酸 化 $\mathrm{HOOC} \longrightarrow-\mathrm{COOH}$

iii. 安息香酸からテレフタル酸の合成 安息香酸より テレフタル酸を得る合成法 ${ }^{59}$ は第 2 ヘンケル法とも呼ば れ, 炭酸カリ, $\mathrm{Cd}$ 系触媒などの存在下に 安息香酸カリ を炭酸ガス加圧下で $400 \sim 450^{\circ} \mathrm{C}$ に約 6 時間反応させる もので収率は約 $90 \%$ である。

2<smiles>CC(=O)OCc1ccccc1C(=O)OCc1ccccc1</smiles>

\section{iv. 安息香酸よりフエノールとテレフタル酸の同時合} 成 野口 ${ }^{63)}$ らはつぎの反応を行なってフェノールとテレ フタル酸の 同時合成を行なっている。すなわち $p$ メチ ルベンゾフェノンを酸化して $p$-カルボキシベンゾフェ ハンとしたのち過酸によってテレフタル酸モノフェニル エステルとし, 加水分解してフェノールとテレフタル酸 を同時に合成しようとするものである。

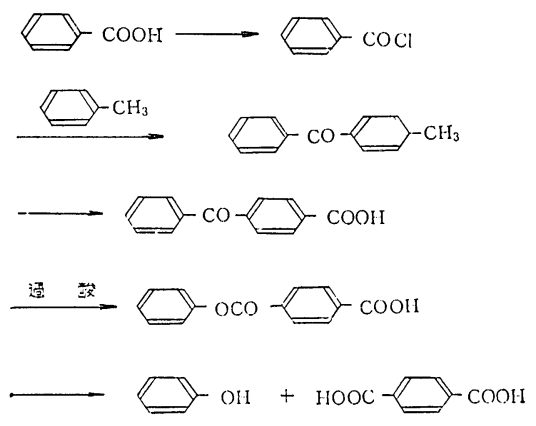

2. ベンゼンジカルボン酸 無水フタル酸はナフタ リンの接触気相酸化で合成されてきたが，ナフタリンの 供給不足, フタル酸の 需要の 急增などのため $o$-キシレ ンの酸化による無水フタル酸の製造が始められている。 用途としてはアルキッド樹脂塗料, 可塑剤, ヘンケル法 によるテレフタル酸合成原料, 染料その他などがあり， 最近ではジアリルフタレート樹脂などの用途む開発され ている。

フタル酸よりテレフタル酸の合成はヘンケル法 ${ }^{59}$ とし て知られているものでフタル酸ジカリウム塩を CdI の ような触媒を用いて炭酸ガス加圧下に $350 \sim 450^{\circ} \mathrm{C}$ に加 熱するもので，この方法で得られるテレフタル酸の純度 が $p$-キシレンの酸化によるものより一般に良好である といわれており，わが国で工業化されている。

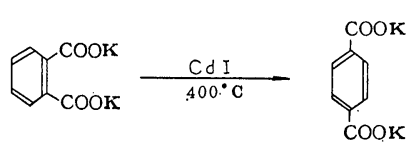

テレフタル酸は $p$-キシレンの酸化, フタル酸, 安息香 酸のヘンケル法による熱転位などで製造されている。テ レフタル酸はほとんど大部分がポリエステル瀻維に使用 され，その他にフイルムとしてあるいは電線用絶縁塗料 にも使用されている。

3. ベンゼンポリカルボン酸 石炭を酸化して得ら れるベンゼンカルボン酸の主成分はトリカルボン酸およ びテトラカルボン酸であり，これらの分離が困難である ことから主として混合物としての用途が開発されてい る。これらの用途としては酸混合物としてコーテイング に，エステル化してポリエステル樹脂としてあるいは脱 炭酸などを行なって需要の多いベンゼンジカルボン酸の 合成などが研究されている。

i. 酸混合物の利用 水可溶酸 (coal acid) を warp size として使用出来ることが報告されている ${ }^{64,65)}$ 。これ は縦系をコーテイングして保護し, 使用後は容易に除去 できることが必要であるが, coal acid が水溶性のため 
水洗除去できることおよびその水溶液を乾固すれば比較 的強いフイルムを形成することを利用したものであり， 摩擦抵抗や除去効果なども検討されており，十分実用で きるものである。同様に coal acid でガラス, 紙, 木, プラスチック材や金属の表面をコーテイングして ${ }^{66)}$, こ れらの表面を保護し, 耐火性, 耐有機溶剤性を増すこと ができる。なおこれらのコーテイングは水洗して除くこ とが出来るため加工時の中閒工程で使用することができ る。また coal acid でポリスチレン粒子をコーテイング するとポリスチレン粒子中に含まれた発泡剤の経時変化 を減少できる゙7)。また $\mathrm{Al}_{2}\left(\mathrm{SO}_{4}\right)_{3}-\mathrm{NaHCO}_{3}$ のような発 泡剂に $0.05 \sim 5 \%$ 程度の coal acid を添加して泡を安定 化させることも出来るようである ${ }^{68)} 。$

ii. ポリエステル樹脂, ポリアミド樹脂として Dow Chemical では coal acid が水可溶性であり, 樹脂化能 力, フイルム形成能力をもつことから，これらの性質を 利用して水可溶性, 熱硬化性樹脂の原料として用途を見 出している ${ }^{64)}$ 。水可溶性の樹脂であれば有機溶剤が不要 となり手軽に使用することができる。この種の樹脂とし ては coal acid に(1) アルカノールアミン，(2) アルキ レンオキシド，(3) ポリヒドロキシ化合物，(4) ポリア ミンなどを反応させて製造するものである。

$$
\begin{aligned}
\mathrm{R}(\mathrm{COOH})_{3}+ & \mathrm{HN}\left(\mathrm{CH}_{2} \mathrm{CH}_{2} \mathrm{OH}\right)_{2} \\
& \longrightarrow \mathrm{R}\left(\mathrm{COOCH}_{2}-\right)\left(\mathrm{CONCH}_{2}-\right) \\
\mathrm{R}(\mathrm{COOH})_{3}+ & \mathrm{HOCH}_{2} \mathrm{CH}_{2} \mathrm{OH} \\
& \longrightarrow \mathrm{R}\left(\mathrm{COOCH}_{2}-\right)_{3} \\
\mathrm{R}(\mathrm{COOH})_{2}+ & \mathrm{H}_{2} \mathrm{~N}\left(\mathrm{CH}_{2}\right)_{\mathrm{n}} \mathrm{NH}_{2} \\
& \longrightarrow \mathrm{R}\left(\mathrm{CONHCH}_{2}-\right)_{2} \\
\mathrm{R}(\mathrm{COOH})_{2}+ & \stackrel{\mathrm{CH}_{2}-\mathrm{CH}_{2}}{\mathrm{O}^{\prime}}
\end{aligned}
$$$$
\longrightarrow \mathrm{R}(\mathrm{COOH})\left(\mathrm{COOCH}_{2} \mathrm{CH}_{2} \mathrm{OH}\right)
$$

アルカノールアミンとしてはモノー, ジ-, トリエタノ ールアミンなど，アルキレンオキシドとしてはエチレン オキシド, プロピレンオキシド, ブチレンオキシドなど, ポリヒドロキシ化合物としてはエチレングリコール，ペ ンタェリスリトール，フェノールホルムアルデヒド縮合 物などを用いている。これらは樹脂の水溶性が低下しな い程度に一部エステル化，あるいはアミド化を行なって 水可溶性樹脂としたものであり，熱硬化性をもってい る。この種の樹脂の一つの用途としては Foundry resin として Foundry sand の結合剤として使用し良好な結果 を得ている。

ベンゼンポリカルボン酸を一価アルコールあるいは多 価アルコールでエステル化して熱硬化性のいろいろの樹 が脂合成されている。たとえばトリメリット酸,トリメシ
ン酸，ヘミメリット酸などベンゼントリカルボン酸ある いはこれらの無水物をまずアルコール $\left(\mathrm{C}_{1 \sim 30}\right)$ であらか ビめエステル化してモノェステルとしたのちグリコール と反応させて樹脂化する ${ }^{69)}$ 。生成樹脂はキシレンに可溶 で金属表面処理に適しており，この樹脂とメラミンーホ ルムアルデヒド樹脂を混合して用いると硬度の良好なフ イルムを形成するとのことである。その他，ピロメリッ 卜酸をはじめ，石炭の硝酸酸化によって得られるベンゼ ンポリカルボン酸混合物をブタノール，オクタノールな どで部分エステル化し，カルボキシル基を 2 個残して他 をエステルとしたのちエポキシ化合物と反応せしめてポ リエステルを得ようとするもの ${ }^{70)}$ ，ピロメリット酸のよ らなカルボキシル基を 3 個以上もったベンゼンカルボン 酸をブタノールやエチレングリコールのような一価アル コール，多価アルコール，あるいはその混合物でエステ ル化したのち，エステル化物に無水マレイン酸のような 不飽和二塩基酸を反応させ，スチレンで橋かけをおこな って可塑性のすぐれた樹脂を製造しようとするもの ${ }^{71)}$,

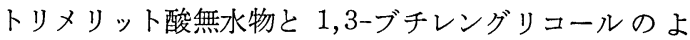
うなグリコールと $100 \sim 240^{\circ} \mathrm{C}$ に加熱してまず酸価 180 〜 $240^{\circ}$ の 反応生成物を 合成し，ついでブタノールのよ らな一価アルコールを反応させてポリステルを製造しコ ーティングに用いようとするもの ${ }^{22}$ や, ベンゼントリカ ルボン酸と多価アルコール（OH 基が 3 個以上）のエス テル化によるポリエステル樹脂の製造 ${ }^{33}$ などがある。ま たトリメシン酸と $\mathrm{C}_{7 \sim 8}$ のアルコールとのエステル化で 得られるトリアルキルエステルをビニルクロライドポリ マーあるいはコポリマーの可塑剤とすること ${ }^{74)}$, 石炭 の硝酸酸化で得られるカルボン酸混合物を高級アルコー ルでエステル化し，潤滑油添加剤として使用することも できる ${ }^{75)}$ 。coal acid の水溶液中でデンプンを加熱して, あるいはあらかじめゲル化したデンプンを coal acid 水 溶液と混合してガラス，プラスチック，アルミニウムな どをコーティングするもの ${ }^{76)}$ ，セルロースあるいはセル ロース誘導体とトリメリット酸のエステルを製造するも の77) どがあり，トリメリット酸トリアルキルエステ ル，たとえばトリブチルエステル，トリイソオクチルエ ステルなどはアブラ虫を殺す作用をもつことも見出され ている ${ }^{78)}$ 。

ベンゼンポリカルボン酸を用いてポリエチレンテレフ タレートなどのポリエステル䋊維，あるいはフイルムの 改質を行なうこともできる ${ }^{79}$ 。たとえばトリメシン酸卜 リメチルエステルをカセイカリと共にメタノール中で加 熱してトリメシン酸ジメチルエステルモノカリウム塩 (1.1 部) とテレフタル酸ジメチルエステル (45.4 部, ) 
エチレングリコール (30.6 部) を加熱してポリエステル を製造するもの ${ }^{80)}$ で，生成したポリエステルはカルボキ シル基をもっており，トリメシン酸の代りにピロメリッ ト酸なども使用できる。

ベンゼンポリカルボン酸にエポキシ化物を反応させて 樹脂化する例も多い。たとえばトリメリット酸無水物に プロピレンオキシドのようなモノー1,2-エポキシ化物を 少量のピリジンの存在下に室温で反応させて白色固体の 中間体を得，これを不飽和脂肪酸と $160 \sim 230^{\circ} \mathrm{C}$ に $\mathrm{hr}$ 加熱して樹脂化させるもので ${ }^{81)}$, 生成樹脂は室温で風乾 すると硬いフイルムを形成する。また coal acid を用い て改質アルキッド樹脂を合成している。たとえば coal acid 1,2-ブチレンオキシド，アマニ油およびキシレ ンを加えて加熱し， $240^{\circ} \mathrm{C}$ に $1.5 \mathrm{hr}$ 保って反忘させる もの ${ }^{82)}$ で，これを $60 \%$ キシレン溶液として用いる。こ の樹脂から得られたフイルムは黄カツ色で硬度は良好で ある。同様に coal acid を原料にしたアルキッド樹脂の 製造に coal acid をクロル化して樹脂化するもの ${ }^{83)}$ があ る。coal acid の $10 \sim 20 \%$ 水溶液に $60^{\circ} \mathrm{C}$ で塩素ガスを 導入してクロル化すると塩素約 $35 \%$ を含んだ coal acid が得られる。クロル化 coal acid とエチレンオキシ ドの重合によって得られた低重合度のポリエチレングリ コールと脂肪酸を樹脂化するものである。無水フタル酸 のかわりにトリメリット酸を用いてアルキッド樹脂が合 成されその性質などが検討されている ${ }^{84)}$ 。また酸無水物 とエポキシ化合物を反応させて樹脂化するさいにピロメ リット酸のような多官能基 $(\mathrm{COOH}$ 基や $\mathrm{OH}$ 基を 3 個 以上有するもの）をもったものを添加し，これを核とし て網状構造をもった熱硬化性ポリエステル樹脂を製造し ようとする特許 ${ }^{85)}$ もる。

ピロメリット酸と芳香族ジアミンと 縮 合させ, 耐熱 性, 耐候性のポリイミド型樹脂が合成されている。中間 のポリアミド縮合物はジメチルホルムアミド，ジメチリ ルアセトアミドなどの極性溶媒に可溶のためフイルム, コーテイングに使用することもでき, 加熱によって不溶 性のポリイミドとなるものである。

その他 coal acid と尿素, モノメチル, ジメチル尿素 等の尿秦誘導体との反応生成物 ${ }^{86)}$ は熱硬化性があり, 一 カへキサメチレテトラミンやポリアミンととをに 175 $\sim 315^{\circ} \mathrm{C}$ に反応させて, 接着剤やバインダーとして使用 したり，また coal acid をグリセロール，エタノールア

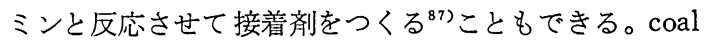
acid をカセイソーダ (50\% 水溶液) で $\mathrm{pH} 4$ 亿 に調製 して反応温度 $20 \sim 60^{\circ} \mathrm{C}$ にてクロル化あるいはブロム化 して得られるハロゲン化 coal acid (平均分子量 300, カ
ルボキシル基当量約 100，ハロゲン含量 12〜30\%）が抗 カビ性を有することが見出されている ${ }^{88)}$ 。

iii. ベンゼンポリカル酸類の熱変化 石炭の酸化生成 物が多種類の成分からなり，おのおのを分離することが 困難であることから酸化生成物のカリウム塩にヘンケル 法を適用して, 酸化生成物を簡単な分離し易い成分に変 成する試みが行なわれている。筆者の研究室において も, これらベンゼンポリカルボン酸類の利用としてテレ フタール酸の合成ならびに関連事項について検討してい るが, たとえば安息香酸カリウム塩およびトリメシン塩 をヨウ化カドミウムの存在下にガスクロマトグラフに直 結した反応管内でヘリウムガス気流中, 一定温度で加熱 せしめた結果, 炭酸ガス, ベンゼンが多量に発生するこ とを確認し，さらにその経時的変化ならびにヨウ化カド ミウムはカルボキシル基の脱炭酸に大いに関与している ことを明らかにした ${ }^{54)}$ 一方, ベンゼンポリカルボン酸 類のポリカリウム塩を単独にたとえばへミメリット酸, トリメシン酸, ピロメリット酸, ベンゼンペンタカルボ ン酸などのポリカリウム塩について, あるいは安息香酸 カリウム塩との混合, たとえばへミメリット酸 ${ }^{55}$ または ベンゼンペンタカルボン酸 ${ }^{56)}$ のポリカリウム塩などとの 混合物に触媒としてヨウ化カドミウムを加え, 炭酸ガス 圧下に一定時間, 一定温度で加熱し, 生成物について検 討した結果, ベンゼンポリカルボン酸単独加熱の場合に は容易にテレフタル酸が生成していることを認めた。さ らに安息香酸との混合加熱の場合にも容易にテレフタル 酸の生成は認められるが, そのおのおのを単独に加熱し た場合の生成テレフタル酸の収量の和よりもさらに多く のテレフタル酸が生成していることから混合加熱の場合 には同一カルボン酸内の反応のみにとどまらず異種カル ボン酸間の反応もテレフタル酸生成に関与していること を認めた。

\section{VI. 結語}

石炭の基本構造がベンゼン核であるという石炭の特質 を有効に活用し，石炭より化学製品を得ようとする石炭 化学の一分野で試験段階にある石炭の酸化についてベン ゼンカルボン酸の製造およびその利用を中心に概観し た。アルカリ酸素酸化法, 硝酸酸化法ともにそれぞれの 特色を有するがアルカリ使用量, 装置の腐食など解決す べき問題も多い。また酸化生成物の組成は複雑でおのお のの成分に分離困難な点も酸化生成物の利用に関して問 題となる。しかしこの分野は石炭化学の一つの新しい方 向を示したものであり，大いに期待される分野である。 (昭和 38 年 9 月 3 日受理) 


\section{文献}

1) W. A. Bone, et al., Proc. Roy. Soc. A 110537 (1926), A 127480 (1930)

2) H. Strache, R. Lant, Kohlen-Chemie 289 (1924); O. Horn, Abhandl. \& Kohle. 8339 (1928); D. H. Bangham. Progress, in Coal Science 267 (1950) Interscience; H. C. Howard, Chemistry of Coal Utilization. vol. 1 (1945) John Wiley; D. W. Kreveln, J. Schuyer., Doal Science p. 203 (1957), Elsevier.

3) 樋口, 有合化 11180 (1953)

4) 安東, 神谷, 有合化 17109 (1959)

.5) F. Fischer, H. Schrader, Abhandl. \&. Kohle. 4342 (1919) 5 160, 235, 267 (1922)

6) H. C. Howard, et al., J. Am. Chem. Soc. 61 2398 (1939)

77) H. C. Howard, et al., Ind. Eng. Chem. 442784 (1952)

(8) J. E. Germaim, et al., Bull. Soc. Chim. France 1962779

9) 神谷, 工化 59197 (1956)

10）神谷, 工化 61197 (1958)

11) 神谷, 工化 63752 (1960)

12) H. C. Howard, et al., Ind. Eng. Chem. 441409 (1952)

13) 神谷, 工化 62106 (1959)

14）神谷, 中野, 工化 621571 (1959)

15) 神谷, 工化 61 337 (1958)

16) H. C. Howard, et al., J. Am. Chem. Soc. 73 3873 (1951)

17) O. Grosskinsky, Glückauf. 88376 (1952)

18) A. Benning, Brennstoff-Chem. 3638 (19.55)

19) B. Jüttner, Brennstoff-Chem. 3780 (1956)

20) 神谷, 工化 60246 (1957)

21) 神谷, 工化 65382 (1962)

22) 神谷, 工化 611593 (1958)

:23) 神谷, 工化 611169 (1958)

:24) 神谷, 工化 642165 (1961)

25) 神谷, 工化 611596 (1958)

:26) 神谷, 工化 621563 (1959)

27) 神谷, 工化 621567 (1959)

28) H. C. Howard, et al., J. Am. Chem. Soc. 57 2322 (1935)

29) A. T. Tadzhiev, Uzbek. Khim. Zhur. 1961 No. 1, 65, CA 5610467 (1962)

30) C. R. Kinney, K. F. Ockert, Ind. Eng. Chem. 48327 (1956)

31) M. A. Hammer, et al., U.S. Bur. Mines, Rept. Invest No. 5782 p. 18. (1961)

32) $G P 935,967$ (1955)

33) $G P 766,206$ (1952)

34) $G P$ 1,089,124 (1960)

35) B. Jüttner, Brennstoff-Chem. 42320 (1961)

36) GP 766,205 (1952)

:37) R. V. Lacal, Combustible 18763 (1958), CA 55
9835 (1961)

38) GP 879,103 (1953)

39) O. Grosskinsky, B. Jüttner, Brennstoff-Chem. 39 7 (1958)

40) $G P 766,204$ (1952)

41) $G P 1,002,315$ (1957)

42) $G P$ 1,017,605 (1957)

43) $G P$ 1,021,349 (1957)

44) $C A$ 53, 22846 (1959)

45) $G P$ 1,020,620 (1957)

46) 安東, 神谷, 然料協誌 38638 (1959)

47) USP 2,785, 198

48) H. C. Howard, et al., J. Am. Chem. Soc. 74 3239 (1952)

49) R. S. Montgomery, Ind. Eng. Chem. 471274 (1955)

50) 加藤ら, 燃料協誌 37423 (1958)

51) 筒井ら，九州鉱山学会誌 27532 (1959)

52) Kurt, et al., Brennstoff-Chem. 35275 (1954)

53) G. R. Boreham, et al., J. Appl. Chem. 6329 (1956)

54）平尾ら，日化 16 年会にて発表 (1963.4)

55) 平尾ら, 工化 631475 (1960)

56) 平尾ら，日化九州支部常会で発表(1963)

57) USP 2,766,294; 2,727,926; 2,852,567; $2,954,407$

58) Belg. P 582,793

59）小方, 化学工簐 11148 (1958); 同前, 有合化 19570 (1961)

60) W. W. Kaeding, et al., Ind. Eng. Chem. 53 805 (1961)

61) W. Schoo., Rec. trav. chim. 80134 (1961)

62) 加藤ら，日化 14 年会要旨集 (1961)

63) 野口ら, 有合化 $21377,385,391,466,520$ (1963)

64) W. L. Archer, et al., Ind. Eng. Chem. 52849 (1960)

65) USP 2, 875,099 (1959); 2, 875, 100 (1959)

66) USP 2, 991,189 (1961)

67) USP 3, 013, 894 (1962)

68) USP 3, 022,251 (1962)

69) USP 2, 939, 857 (1960)

70) $G P 1,055,812$ (1959); GP 1, 115, 014 (1959)

71) $B P 847,407$ (1960)

72( USP 3, 026, 300 (1962)

73) USP 2,985, 603 (1961)

74) $G P 1,103,578$ (1959)

75) $G P$ 1, 035, 832 (1958)

76) USP 2, 887, 399 (1959)

77) USP 3, 022, 287 (1962)

78) USP 2, 955, 979 (1960)

79) $B P 853,442$ (1960)

80) $B P$ 856, 917 (1960)

81) USP 3, 012, 979 (1961)

82) USP 2, 965, 587 (1960)

83) USP 2, 971, 932 (1960)

84) P. W. Sherwoad, Fette, Seifen, Austrichmittel 631045 (1961); CA 5613041 (1962)

85) $B P 839,773(1960)$

86) USP 3, 004, 954 (1957)

87) USP 3, 005, 743 (1957)

88) USP 2, 929, 838 (1960) 